Jurnal Inkofar * Volume 5 No. 1, Juli 2021 * E-ISSN: 2581-2920

Tersedia secara online di: http://www.politeknikmeta.ac.id/meta/ojs/

\title{
PENGARUH ADIKSI GAWAI TERHADAP PRESTASI BELAJAR MAHASISWA PRODI DIPLOMA III AKADEMI FARMASI YARSI PONTIANAK
}

\author{
Fadli $^{1}$, Adhisty Kharisma Justicia ${ }^{2}$, Aulia Azanita ${ }^{3}$ \\ 1,2,3Akademi Farmasi Yarsi Pontianak/ fadliapoteker@yahoo.com
}

\begin{abstract}
Gawai addiction is addiction to gadgets so that it spends more time using gadgets. Gawai addiction can have an impact on learning achievement. This study aims to determine the effect and how far the level of gadget addiction is on the learning achievement of students in Diploma III of Akademi Farmasi Yarsi Pontianak. The population in this study were students of the Akademi Farmasi Yarsi Pontianak batch of 2019. The sample collection technique used was simple random sampling with 30 respondents. This research method is a survey method with the type of observational analytic research using a questionnaire. The analysis technique in this study uses the t test to test the research hypothesis and to see the effect of the relationship between the independent variable (gadget addiction) and the dependent variable (learning achievement), a simple linear regression test is used. The results obtained a significance value of $0.029<0.05$, it can be concluded that there is an influence on the relationship between device addiction and learning achievement and the t count value is 2.307> 2.048, so it can be concluded that the hypothesis in this study is accepted and the effect of the independent variable (gadget addiction) on the variable bound (Learning Achievement) amounted to 16.0\%. The conclusion of this study is that there is a significant negative relationship between device addiction and student achievement of the Diploma III Akademi Farmasi Yarsi Pontianak.
\end{abstract}

Keywords : Addiction, Gawai, Learning Achievement

\begin{abstract}
ABSTRAK
Adiksi Gawai merupakan kecanduan terhadap gadget sehingga lebih banyak menghabiskan waktu untuk menggunakan gadget. Adiksi Gawai dapat berdampak terhadap prestasi belajar. Penelitian ini bertujuan untuk mengetahui pengaruh dan seberapa jauh tingkat Adiksi Gawai terhadap Prestasi Belajar Mahasiswa Prodi Diploma III Akademi Farmasi Yarsi Pontianak. Populasi dalam penelitian ini adalah Mahasiswa Akademi Farmasi Yarsi Pontianak Angkatan Tahun 2019. Teknik pengumpulan sampel yang digunakan yaitu Simpel Random Sampling dengan 30 responden. Metode penelitian ini adalah metode survey dengan jenis penelitian observasi analitik dengan menggunakan kuesioner. Teknik analisis pada penelitian ini menggunakan uji t untuk uji hipotesis penelitian dan untuk melihat pengaruh hubungan antara variabel bebas (Adiksi Gawai) dan variabel terikat (Prestasi Belajar) digunakan uji regresi linier sederhana. Hasil penelitian didapatkan nilai signifikansi sebesar 0,029 $<0,05$ maka dapat disimpulkan bahwa terdapat pengaruh hubungan antara adiksi gawai dan prestasi belajar dan nilai t hitung sebesar 2,307 > 2,048 maka dapat disimpulkan bahwa hipotesis pada penelitian ini diterima dan pengaruh variabel bebas (Adiksi Gawai) terhadap variabel terikat (Prestasi Belajar) adalah sebesar 16,0 \%. Kesimpulan dari penelitian ini yaitu terdapat hubungan negatif yang signifikan antara Adiksi Gawai Terhadap Prestasi Belajar Mahasiswa Prodi Diploma III Akademi Farmasi Yarsi Pontianak.
\end{abstract}

Kata Kunci : Adiksi, Gawai, Prestasi Belajar

\section{PENDAHULUAN}

Salah satu tujuan pendidikan adalah untuk menciptakan manusia yang berkualitas. Kualitas manusia yang dibutuhkan oleh bangsa Indonesia pada masa yang akan datang adalah yang mampu menghadapi persaingan yang semakin ketat dengan bangsa lain di dunia. Kualitas manusia Indonesia tersebut dihasilkan melalui penyelenggaraan pendidikan yang bermutu (Mantiri, 2019). 
Untuk menciptakan SDM yang berkualitas dan terampil yang diperlukan adalah pendidikan. Pendidikan merupakan usaha agar manusia dapat mengembangkan potensi dirinya melalui proses pembelajaran dan/atau cara lain yang dikenal dan diakui oleh masyarakat. Keberhasilan mahasiswa dalam bidang akademik ditandai dengan prestasi akademik yang dicapai, ditunjukkan melalui indeks prestasi (IP) maupun indeks prestasi kumulatif (IPK). Dari hasil observasi di Akademi Farmasi Yarsi Pontianak beberapa mahasiswa lebih banyak menghabiskan waktunya untuk bermain gawai dan berdasarkan hasil indeks prestasi dari 10 mahasiswa $75 \%$ nya memiliki IPK dibawah 3,00 dan menunjukkan adanya penurunan prestasi dari semester I ke semester II akibat pengaruh penggunaan gawai yang terlalu lama (kecanduan gawai).

Penelitian sebelumnya menyebutkan bahwa sebagian besar efek negatif penggunaan gawai yang berlebihan (adiksi) dapat berpengaruh serius pada aspek-aspek akademik remaja dari segi personalnya. Di antaranya efek negatif yang paling sering ditemukan adalah menurunnya prestasi akademik remaja (Utami, 2019). Penggunaan gawai dapat berdampak baik maupun buruk terhadap prestasi belajar mahasiswa tergantung bagaimana mereka akan memanfaatkannya. Menggunakan gawai dapat berpengaruh dampak negatif terhadap performa akademik siswa apabila tidak memiliki manajemen waktu yang baik dalam penggunaan gadget (Fitri et al., 2018). Berdasarkan penelitian ini, prestasi belajar dapat dipengaruhi oleh penggunaan gawai secara terus menerus tanpa bisa mengontrol diri. Maka dari itu peneliti tertarik untuk melakukan penelitian lebih lanjut dengan judul "Pengaruh Adiksi Gawai Terhadap Prestasi Belajar Mahasiswa Prodi Diploma III Akademi Farmasi Yarsi Pontianak."

\section{LANDASAN TEORI}

\subsection{Prestasi Belajar}

Prestasi belajar adalah hasil atau taraf kemampuan yang telah dicapai siswa setelah mengikuti proses belajar mengajar dalam waktu tertentu, baik berupa perubahan tingkah laku, keterampilan, dan pengetahuan. (Hidayat \& Junianto, 2017)

Hasil dari pengukuran terhadap peserta didik merupakan prestasi dalam belajar dimana meliputi faktor kognitif, afektif, dan psikomotor setelah menjalani proses pembelajaran yang diukur dengan menggunakan instrumen tes atau instrumen yang relevan. Prestasi belajar adalah hasil yang dicapai oleh siswa setelah mengikuti pembelajaran dalam waktu yang telah ditentukan. Hasil belajar tersebut dapat berbentuk angka, huruf, simbol, maupun kalimat yang menyatakan keberhasilan yang dicapai siswa selama proses pembelajaran (Moh Zaiful Rosyid, DKK, hal.8-9. 2019).

\subsection{Gawai}

Gawai merupakan teknologi yang pemakaiannya merata pada semua usia, termasuk anak-anak usia dibawah 5 tahun (Fajariah, 2018). Secara istilah gadget atau gawai berasal dari bahasa Inggris merupakan perangkat elektronik yang memiliki fungsi khusus. Dalam bahasa indonesia gadget disebut dengan gawai.

\subsection{Adiksi Gawai}

Adiksi gawai dapat diartikan sebagai ketergantungan, dimana individu tersebut akan terus menerus melakukannya (young \& Rodgers dalam wijanarko, 2016). Sehingga dapat disimpulkan bahwa kecanduan gawai dapat merugikan baik itu secara fisik, psikis, maupun spiritual karena dapat menyebabkan ketergantungan bagi individu.

Menurut Young dan Rodgers dalam wijanarko (2016) ada 4 indikator adiksi gawai yaitu :

1. Terlalu memikirkan gawai

2. Tidak dapat mengontrol diri ketika menggunakan gawai

3. Cemas apabila tidak menggunakan gawai

4. Tidak mengenal waktu dalam menggunakan gawai 


\section{METODOLOGI PENELITIAN}

Penelitian ini merupakan penelitian surey dengan jenis penelitian observasi analitik. Penelitian ini dilaksanakan di Kampus Akademi Farmasi Yarsi Pontianak, Kalimantan Barat, pada bulan Februari sampai dengan Maret 2021. Populasi adalah seluruh subjek atau objek yang memiliki karakteristik sesuai dengan ketentuan yang akan diteliti (Notoatmdjo, 2010). Populasi pada penelitian ini yaitu sebanyak 120 mahasiswa pada tingkat 2. Menurut Sugiyono (2019), ukuran sampel yang layak dalam penelitian adalah antara 30 sampai dengan 500. Sampel yang digunakan pada penelitian ini yaitu 30 responden dengan menggunakan teknik probability sampling dengan teknik yang digunakan yaitu Simpel Random Sampling yang merupakan teknik pengambilan sampel yang dilakukan secara acak tanpa memperhatikan strata yang ada pada populasi (Susilawati, 2020). Instrumen pengumpulan data menggunakan kuesioner yang disusun berdasarkan indikator variabel adiksi gawai dan untuk variabel prestasi belajar menggunakan observasi nilai IPK. Kuesioner dibagikan dengan menggunakan google form dengan menyebarkan link kuesioner kepada mahasiswa tingkat 2 Prodi Diploma III Akademi Farmasi Yarsi Pontianak. Prosedur pengolahan data dilakukan melalui tahap editing, scoring, coding, tabulating. Data dianalisis dengan prosedur analisis univariat dan analisis bivariat.

\subsection{Analisis Data}

Analisis data yang lakukan pada penelitian ini dengan uji hipotesis uji t menggunakan bantuan software SPSS.25, menggunakan taraf signifikansi 5\% atau 0,05.

a. Jika $t$ hitung $<\mathrm{t}$ tabel, maka hipotesis ditolak

b. Jika $t$ hitung $\geq \mathrm{t}$ tabel, maka hipotesis diterima

Setelah itu dilanjutkan dengan analisis regresi linier sederhana untuk melihat pengaruh hubungan antara variabel bebas (adiksi gawai) dan variabel terikat (Prestasi belajar)..

\subsection{Hasil Dan Pembahasan}

\subsubsection{Analisis Univariat}

Tabel 1. Frekuensi Karakteristik Responden

\begin{tabular}{cccc}
\hline No & Karakteristik & Frekuensi & Persentase \\
\hline $\mathbf{1}$ & Umur & & \\
& 19 tahun & 20 & $66,67 \%$ \\
& 20 tahun & 10 & $33,33 \%$ \\
Total & 30 & $100 \%$ \\
$\mathbf{2}$ & Jenis Kelamin & & \\
& Laki-laki & 4 & $13,33 \%$ \\
& Perempuan & 26 & $86,67 \%$ \\
& Total & 30 & $100 \%$ \\
\hline
\end{tabular}

Berdasarkan data pada Tabel 1 dapat diketahui bahwa responden yang berumur 19 tahun sebanyak 20 orang responden $(66,67 \%)$ dan berumur 20 tahun sebanyak 10 orang responden $(33,33 \%)$. Pada jeniskelamin dapat dilihat bahwa responden dengan jenis kelamin perempuan sebanyak 26 responden $(86,67 \%)$ dan sebagian kecil berjenis kelamin laki-laki yaitu sebanyak 4 responden $(13,33 \%)$.

Tabel 2. Distribusi Persentase Adiksi Gawai pada Mahasiswa Tingkat 2 Akademi Farmasi Yarsi Pontianak

\begin{tabular}{lll}
\hline Adiksi Gawai & N & Persentase \\
\hline Sedang & 13 & $43,33 \%$ \\
Ringan & 17 & $56,67 \%$ \\
Total & $\mathbf{3 0}$ & $\mathbf{1 0 0 \%}$ \\
\hline
\end{tabular}

Berdasarkan data pada Tabel 2 didapatkan hasil mayoritas responden tingkat kecanduan terhadap gadget (Adiksi Gawai) di kategori ringan yaitu sebesar 56,67\%. Sedangkan 43,33\% lainnya di kategori sedang. 
Jurnal Inkofar * Volume 5 No. 1, Juli 2021 * E-ISSN: 2581-2920

Tersedia secara online di: http://www.politeknikmeta.ac.id/meta/ojs/

Tabel 3. Distribusi Persentase Prestasi Belajar pada Mahasiswa tingkat 2 Akademi Farmasi Yarsi Pontianak

\begin{tabular}{lll}
\hline Prestasi Belajar & N & Persentase \\
\hline Cukup Memuaskan & 11 & $36,67 \%$ \\
Memuaskan & 19 & $63,33 \%$ \\
Total & $\mathbf{3 0}$ & $\mathbf{1 0 0 \%}$ \\
\hline
\end{tabular}

Berdasarkan data pada Tabel 3 didapatkan hasil mayoritas responden tingkat prestasi belajar memuaskan yaitu sebesar 63,33\%. Sedangkan 36,67\% lainnya di kategori cukup memuaskan.

Berdasarkan Tabel II dan Tabel III dapat dilihat semakin rendah tingkat kecanduan terhadap gadget (Adiksi Gawai), maka semakin tinggi tingkat prestasi belajar mahasiswa, begitu pula sebaliknya.

\subsubsection{Analisis Bivariat}

Tabel 4. Data Uji Normalitas dengan SPSS Tests of Normality

\begin{tabular}{lccrrrr}
\hline & \multicolumn{3}{c}{ Kolmogorov-Smirnov $^{\mathrm{a}}$} & \multicolumn{3}{c}{ Shapiro-Wilk } \\
\cline { 2 - 8 } & Statistic & Df & \multicolumn{1}{c}{ Sig. } & Statistic & Df & \multicolumn{1}{c}{ Sig. } \\
\hline Adiksi Gawai & 0,136 & 30 & 0,165 & 0,948 & 30 & 0,149 \\
\hline Prestasi Belajar & 0,140 & 30 & 0,138 & 0,971 & 30 & 0,575 \\
\hline
\end{tabular}

a. Lilliefors Significance Correction

Berdasarkan hasil uji normalitas diketahui nilai signifikansi Shapiro-Wilk yaitu pada variabel adiksi gawai sebesar 0,149 dan variabel prestasi belajar sebesar 0,575. Angka sig. Shapiro-Wilk tersebut lebih tinggi dibandingkan dengan taraf signifikansi 5\% $(0,05)$ atau sig. $>0,05$, maka dapat disimpulkan bahwa data kedua variabel berdistribusi normal.

Tabel 5. Data Uji Regresi Linier Sederhana dengan SPSS Model Summary

\begin{tabular}{llrrr}
\hline Model & R & R Square & $\begin{array}{c}\text { Adjusted R } \\
\text { Square }\end{array}$ & $\begin{array}{l}\text { Std. Error of } \\
\text { the Estimate }\end{array}$ \\
\hline 1 & $0,400^{\mathrm{a}}$ & 0,160 & 0,130 & 0,29409 \\
\hline
\end{tabular}

a. Predictors: (Constant), Adiksi Gawai

Berdasarkan tabel hasil uji regresi sederhana menjelaskan besarnya nilai korelasi/hubungan (R) yaitu sebesar 0,400. Dari output tersebut diperoleh koefisien determinasi (R square) sebesar 0,160 yang mengandung arti bahwa pengaruh variabel bebas terhadap variabel terikat adalah sebesar $16,0 \%$. hal ini menunjukkan pengaruh yang rendah tetapi pasti antara Adiksi Gawai dan Prestasi Belajar. Data yang dihitung dengan uji regresi linier sederhana diperoleh nilai $r$ sebesar 0,400. Hal tersebut menyatakan adanya pengaruh adiksi gawai terhadap prestasi belajar pada tingkat sedang. Hal ini juga didukung oleh penelitian terdahulu, bahwa penggunaan gadget terdapat pengaruh yang mempengaruhi nilai prestasi mahasiswa (Nurmalasari, 2018).

Tabel 6. Coefficients Regresi Linier Sederhana Coefficients $^{\mathrm{a}}$

\begin{tabular}{|c|c|c|c|c|c|c|}
\hline \multirow[b]{2}{*}{ Model } & & \multicolumn{2}{|c|}{ Unstandardized Coefficients } & $\begin{array}{l}\text { Standardized } \\
\text { Coefficients }\end{array}$ & \multirow[b]{2}{*}{$\mathrm{T}$} & \multirow[b]{2}{*}{ Sig. } \\
\hline & & $\mathrm{B}$ & Std. Error & Beta & & \\
\hline \multirow[t]{2}{*}{1} & (Constant) & 3,943 & 0,349 & & 11,287 & 0,000 \\
\hline & Adiksi Gawai & $-0,287$ & 0,125 & $-0,400$ & $-2,307$ & 0,029 \\
\hline
\end{tabular}

a. Dependent Variable: Prestasi Belajar

Tabel diatas adalah tabel koefisien dimana diketahui nilai constand (a) sebesar 3,943 sedangkan nilai $b$ (koefisien regresi) sebesar $-0,287$. Sehingga persamaan regresi dapat ditulis : 
Jurnal Inkofar * Volume 5 No. 1, Juli 2021 * E-ISSN: 2581-2920

Tersedia secara online di: http://www.politeknikmeta.ac.id/meta/ojs/

$$
\begin{gathered}
\mathrm{Y}=\mathrm{a}+\mathrm{bX} \\
\mathrm{Y}=3,943-0,287
\end{gathered}
$$

Persamaan diatas dapat menunjukkan bahwa variabel Adiksi Gawai memiliki nilai negatif (-) 0,287 yang diartikan bahwa apabila terjadi penurunan Adiksi Gawai sebesar 1\% maka akan terjadi kenaikan nilai Prestasi Belajar sebesar 0,287\%, sehingga dapat dikatakan bahwa arah pengaruh variabel X (Adiksi Gawai) terhadap variabel Y (Prestasi Belajar) adalah bernilai negatif.

Berdasarkan nilai signifikansi dari tabel coefficients didapatkan nilai signifikansi sebesar 0,029< 0,05 , sehingga dapat disimpulkan bahwa variabel X (Adiksi Gawai) berpengaruh terhadap $\mathrm{Y}$ (Prestasi Belajar).

Berdasarkan hasil yang diperoleh pada tabel coefficients diketahui nilai $\mathrm{t}_{\text {hitung }}$ sebesar -2,307. Simbol negative yang terdapat pada uji t menyatakan slope $\beta 1$. Jika nilai koefisien $\beta 1$ berslope negatif, maka nilai $t_{\text {hitung }}$ pun akan bernilai negatif. Sehingga angka yang digunakan dalam uji $t$ hanyalah angka $t_{\text {hitung, }}$, tanpa menyertakan slope atas nilai $t_{\text {hitung }}$ tersebut (Halin, 2017). Oleh karena itu didapatkan hasil $t_{\text {hitung }}$ sebesar $2,307>2,048$, nilai $t_{\text {hitung }}$ tersebut lebih besar dari $t_{\text {tabel, }}$ maka dapat disimpulkan bahwa hipotesis diterima. Jadi dapat disimpulkan bahwa terdapat pengaruh Adiksi Gawai terhadap Prestasi Belajar Mahasiswa Prodi Diploma III Akademi Farmasi Yarsi Pontianak. Sehingga menunjukkan bahwa ada pengaruh signifikan terhadap prestasi belajar. Gawai atau gadget dapat digunakan untuk mencari informasi atau mengerjakan tugas tetapi jika tidak dapat mengontrol dalam penggunaannya maka akan berdampak negatif. Hal ini didukung oleh penelitian yang dilakukan oleh kendiri (2020), menyatakan bahwa penggunaan gadget bisa mempengaruhi performa nilai akademik. Jika siswa sehari-hari menggunakan gadget secara terusmenerus akan mengakibatkan kecanduan. Siswa kecanduan akan aplikasi yang digunakan seperti media social, game, dan internet. Dalam hal ini siswa akan mengalami nilai akademik yang menjadi buruk. Berdasarkan penelitian yang dilakukan oleh Rozalia (2017), menyatakan bahwa semakin tinggi intensitas pemanfaatan gadget, maka prestasi siswa semakin menurun.

\section{KESIMPULAN DAN SARAN \\ 4.1 Kesimpulan}

Berdasarkan hasil penelitian yang dilakukan pada Pengaruh Adiksi Gawai Terhadap Prestasi Belajar Mahasiswa Prodi Diploma III Akademi Farmasi Yarsi Pontianak didapatkan kesimpulan bahwa Adiksi Gawai memiliki pengaruh Terhadap Prestasi Belajar Mahasiswa Prodi Diploma III Akademi Farmasi Yarsi Pontianak dengan nilai signifikansi sebesar 0,029 $<0,05$ dan nilai thitung sebesar 2,307> 2,048 nilai thitung tersebut lebih besar dari tabel, maka dapat disimpulkan bahwa hipotesis diterima. Dimana hipotesis penelitian ini adalah Adiksi Gawai Berpengaruh Terhadap Prestasi Belajar Mahasiswa Prodi Diploma III Akademi Farmasi Yarsi Pontianak. Dari hasil data yang telah diuji diperoleh koefisien determinasi ( $\mathrm{R}$ square) sebesar 0,160, maka pengaruh variabel bebas terhadap variabel terikat adalah sebesar 16,0\%. Pada uji regresi linier sederhana diperoleh nilai $r$ sebesar 0,400. Hal tersebut menyatakan adanya pengaruh Adiksi Gawai terhadap Prestasi Belajar pada tingkat sedang.

\subsection{Saran}

Diharapkan untuk peneliti selanjutnya dapat melakukan penelitian Adiksi Gawai terhadap gangguan emosi dan perilaku remaja. Penelitian ini juga dapat dijadikan sebagai acuan untuk peneliti selanjutnya.

\section{DAFTAR PUSTAKA}

Utami, A. N., Farida, K.2019. Dampak Negatif Adiksi Penggunaan Smartphone terhadap AspekAspek Akademik Personal Remaja. Perspektif Ilmu Pendidikan, volume 33 No. 11 April 2019.

Fitri, S., Nurjanah, N., Astuti, W. 2018. Penerapan Data Mining Untuk Evaluasi Kinerja Akademik Mahasiswa (Studi Kasus: Umtas). Simetris : Jurnal Teknik Mesin, Elektro Dan Ilmu Komputer, 9(1), 633-640.

Fajariah, S. N., dkk. 2018. Dampak Penggunaan Gawai Terhadap Perkembangan Anak. Sari Pediatri. Volume 20 No. 2 Agustus 2018. 
Mantiri, J. 2019. Peran Pendidikan dalam Menciptakan Sumber Daya Manusia Berkualitas di Provinsi Sulawesi Utara. Jurnal Civic Education, Volume 3 No. 1

Moh Zaiful R, dkk. 2019. Prestasi Belajar. Literasi Nusantara.Cepokomulya, Kepanjen, Malang. Sugiyono. 2019. Metodologi Penelitian Kuantitatif, Kualitatif Dan R\&D. CV Alfabeta : Bandung Halin, Hamid.,dkk.2017.Pengaruh Harga Jual Kaca Patri Jenis Silver Terhadap Nilai Penjualan Pada CV.Karunia Kaca Palembang Tahun 2004-2015.Jurnal Ecoment Global Volume 2 Nomor 2. Agustus 2017.2540-816X.

Hidayat, A. R., \& Junianto, E. (2017). Pengaruh Gadget Terhadap Prestasi Siswa SMK Yayasan Islam Tasikmalaya Dengan Metode TAM | Hidayat | Jurnal Informatika. Jurnal Informatika, 4(2), 163-173.

Kendiri, D. 2020.Studi Konseptual Pengaruh Gadget Terhadap Performa Akademik.Jurnal Conference on Business,Social Sciences and Innovation Technology Volume 1 Nomor 2.Agustus 2020.

Notoadmodjo, S. 2012. Metodologi penelitian kesehatan Jakarta rineka cipta

Nurmalasari., dkk.2018.Pengaruh Penggunaan Gadget Terhadap Tingkat Prestasi Siswa SMPN Satu Atap Pakisjaya Karawang.Jurnal Ilmu Pengetahuan Dan Teknologi Komputer Volume 3 nomor 2. Februari 2018. 2527-4864.

Rozalia, Maya F.2017.Hubungan Intensitas Pemanfaatan Gadget Dengan Prestasi Belajar Siswa Kelas V Sekolah Dasar.Jurnal Pemikiran dan Pengembangan SD Volume 5 Nomor 2.September 2017 hal 722-731.

Susilawati,Anggi.2020.Pengaruh Penggunaan Gadget Terhadap IPK Mahasiswa Pendidikan Fisika UIN AR-RANIRY Banda Aceh.Universitas Islam Negeri AR-RANIRY Darussalam .Banda Aceh.

Wijanarko, setiawati, j., esther, (2016). Ayah ibu baik parenting era digital. Jakarta selatan : keluarga Indonesia bahagia

\section{UCAPAN TERIMAKASIH}

Puji dan syukur penulis panjatkan kepada Allah SWT, karena berkat kelimpahan rahmat, hidayah dan karunia-Nya penelitian ini yang berjudul Pengaruh Adiksi Gawai Terhadap Prestasi Belajar Mahasiswa Prodi Diploma Akademi Farmasi Yarsi Pontianak dapat terselesaikan. Selain itu penulis mengucapkan terimakasih kepada Akademi Farmasi Yarsi Pontianak, Mahasiswa tingkat 2 Akademi Farmasi Yarsi Pontianak, serta semua pihak yang memberikan dukungan dan bantuan dalam penyelesaian penelitian ini.

\section{LAMPIRAN}

\begin{tabular}{|c|l|l|l|l|l|}
\hline \multirow{2}{*}{ No } & \multicolumn{1}{|c|}{ Pernyataan } & \multicolumn{3}{c|}{ Jawaban } \\
\cline { 3 - 7 } \multicolumn{2}{|c|}{} & \multicolumn{1}{|c|}{ SL } & SR & KD & TP \\
\hline \multicolumn{2}{|c|}{ Terlalu Memikirkan Gawai } & & & & \\
\hline 1 & $\begin{array}{l}\text { Merasa tidak nyaman ketika gawai anda tertinggal atau } \\
\text { tidak dapat sinyal }\end{array}$ & & & & \\
\hline 2 & Update status & & & & \\
\hline 3 & Merasa gelisah tidak melihat gawai ketika bangun tidur di & & & & \\
pagi hari & & & & \\
\hline
\end{tabular}




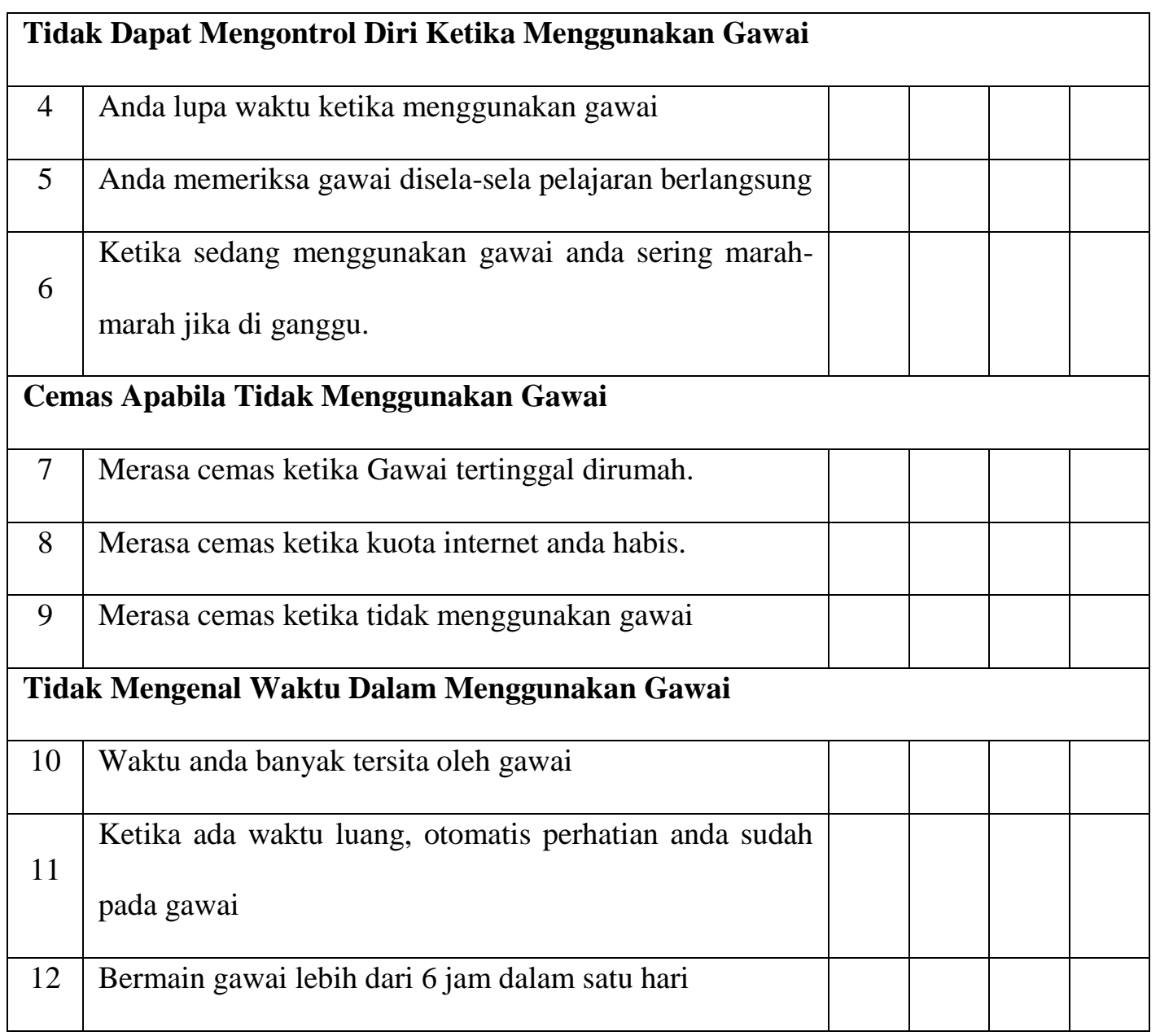

